\title{
THE MINORITY REPORT E A ANÁLISE DA TENTATIVA, DESISTÊNCIA VOLUNTÁRIA E CRIME CONSUMADO NA DOGMÁTICA PENAL BRASILEIRA
}

\author{
Marco Aurélio de Jesus Pio* \\ Márcio Antônio Alves de Oliveira ${ }^{1}$
}

\begin{abstract}
Resumo
$\mathrm{O}$ artigo apresenta análise entre direito e arte como modo de pensar, estudar e produzir cientificamente sobre ciências jurídicas e sociais. O debate ocorre em torno da ficção intitulada "The minority report" escrito em 1956 por Philip Kindred Dick que se tornou o filme "Minority Report" em 2002. Toma-se como ponto de partida a criminologia e dogmática penal para analisar as bases da ficção e suas cenas, destacando os principais temas apresentados pelo autor e comparando-o com o direito penal brasileiro. Foi utilizado o método hipotético-dedutivo, com pesquisa exploratória e bibliográfica, de abordagem predominantemente qualitativa.
\end{abstract}

Palavras-chave: Arte. Direito. Dogmática Penal. Criminologia. Prevenção.

\section{THE MINORITY REPORT AND THE ANALYSIS OF THE ATTEMPT, VOLUNTARY WITHDRAWAL AND CONSUMMATED CRIME IN THE BRAZILIAN CRIMINAL DOGMATIC}

\begin{abstract}
The article presents an analysis between law and art as a way of thinking, studying and producing scientifically on legal and social sciences. The debate takes place around the fiction titled "The Minority Report" written in 1956 by Philip Kindred Dick who became the film "Minority Report" in 2002. It takes as a starting point the criminology and criminal dogmatic to analyze the bases of fiction and its scenes, highlighting the main themes presented by the author and comparing it with the Brazilian criminal law. The hypothetical-deductive method was used, with exploratory and bibliographic research, with a predominantly qualitative approach.
\end{abstract}

Keywords: Art. Right. Criminal dogmatic. Criminology. Prevention.

\footnotetext{
* Graduado em Direito (UFMA), Graduado em Segurança Pública (UEMA), Graduado em Filosofia (UEMA), PósGraduado em Docência do Ensino Superior (IESFMA), Pós-Graduado em Direito Penal e Processo Penal (UNESARJ), Pós-Graduado em Direito Militar (UNIATENEU-CE), Pós-Graduado em Gestão Pública (UEMA), Master of Business Administration em Direito e Processo do Trabalho (PITÁGORAS-MG), Mestre em Segurança Pública (IUPFA), Mestre em Desenvolvimento Socioespacial e Regional (UEMA), Doutorando em Direito (UVA/UNIFACVEST). Professor na Graduação e Pós-Graduação em Direito do Centro Universitário Estácio São Luís. Professor na Universidade Estadual do Maranhão. Coordenador dos Cursos de Pós-Graduação em Direito do Centro Universitário Estácio São Luís. Servidor Público Militar - Oficial Superior de Carreira. E-mail: maximusimperatore@yahoo.com.br

${ }^{1}$ Graduado em Direito (UFMA). Graduação em Segurança Pública (UEMA). MBA em Direito Civil e Processo Civil (Fundação Getúlio Vargas). Pós-graduação em Direito Penal e Processo Penal (Faculdade de Direito Prof. Damásio de Jesus). Pós-graduação em Direito Constitucional (Faculdade de Direito Prof. Damásio de Jesus). Mestrando em Direito (UVA/UNIFACVEST). Atualmente é Membro do Ministério Público do Estado do Maranhão, Promotor de Justiça.
}

Revista de Direito, Arte e Literatura | e-ISSN: 2525-9911 | Belém | v. 5 | n. 2 | p. 99 - 115 | Jul/Dez. 2019. 


\section{INTRODUÇÃO}

O Direito sempre foi uma ciência dinâmica e dialética ${ }^{2}$, mantendo estreita relação com diversos outros ramos do conhecimento, produzindo assim uma proveitosa interdisciplinaridade. Uma dessas possibilidades se dá entre o direito e a arte, posto que a arte é uma maneira de pensar e refletir com criatividade o mundo real e imaginário através da música, artes visuais, cinema, literatura e outras manifestações. Assim, tanto o direito pode ser analisado na arte como a arte no direito.

Entretanto, este enlace entre direito e arte ainda é pouco explorado no meio acadêmico brasileiro como fins de produção científica, o que derradeiramente justifica as pretensões e reflexões deste ensaio, que faremos usando a literatura e principalmente o cinema.

Nosso objetivo, portanto, é analisar a ficção intitulada "O relatório minoritário" ou "The minority report" escrito em 1956 por Philip Kindred Dick ${ }^{3}$ a partir de estudos da criminologia e dogmática penal, destacando os principais temas apresentados na ficção pelo autor, crime e prevenção, e comparando-o com o direito penal brasileiro em busca de construção de conhecimento a partir da arte.

A obra de Philip K. Dick se compõe de uma aquarela de excelentes produções literárias que lhe renderam admiração internacional, sua imaginação fértil e original imprimem discussões amplas e variadas sobre o tempo, realidade, percepções, natureza humana, livre-arbítrio, emoções, direito e justiça, que o levou a ficar entre os autores mais adaptados para o cinema, inclusive com o filme "Minority Report - A Nova Lei" lançado em 2002, dirigido por Steven Spielberg, roteirizado por Scott Frank e estrelado por Tom Cruise.

\footnotetext{
${ }^{2}$ Conforme a concepção dialética de Heráclito de Éfeso (540 a.C. - 470 a.C) em que o mundo está em movimento perpétuo, em oposição ao paradigma de Parmênides.

${ }^{3}$ Foi um escritor norte-americano de ficção científica, nascido no dia 16 de dezembro de 1928 em Chicago e que morreu em Santa Ana no dia 2 de março de 1982. Literariamente explorou em suas obras temas políticos, filosóficos e sociais, indo do autoritarismo, realidades alternativas e até estados alterados de consciência. Apesar de ter tido pouco reconhecimento em vida, a adaptação de vários dos seus romances ao cinema acabou por tornar a sua obra conhecida de um vasto público, sendo aclamado tanto pelo público como pela crítica (CARRÉRE, 2016).
} 
Em síntese, a narrativa ocorre em Washington, EUA, no ano de 2054, apresentando a história de John Anderton, um policial que atua na liderança da Divisão Pré-Crime com a finalidade de impedir a ocorrência de homicídios. Essa prevenção é possível porque a divisão policial conta com ajuda de paranormais (os precogs) que visualizam o futuro e conseguem com antecedência prever o possível assassinato, o nome do suposto criminoso e da vítima, fornecendo imagens do crime, seu modus operandis e hora exata que irá ocorrer.

John Anderton é responsável por analisar o caso, descobrir o local, e com sua equipe impedir a execução do assassinato, prendendo o suposto culpado. Porém, em determinado dia os precogs emitem um visão onde o próprio John Anderton é visto matando uma vítima desconhecida e isso ocorrerá em menos de trinta e seis horas, Anderton se recusa a acreditar que ele será um assassino e por isso foge em busca de respostas que possam evitar a sua condenação, enquanto isso sua própria equipe lhe persegue a fim de efetuar sua prisão.

É, portanto neste enredo que nosso ensaio debaterá a ficção versus a ciência jurídica buscando refletir casos instigantes a partir do estudo das ciências criminais, principalmente a dogmática penal ${ }^{4}$ e criminologia ${ }^{5}$.

Deste modo, em um primeiro momento iremos nos debruçar no estudo do surgimento do crime e o direito criminal, qual são os bens jurídicos protegidos por esse ramo do direito e principalmente discutir sobre a prevenção.

Em seguida o estudo apresenta o conceito analítico de crime, qual o caminho do crime a partir de suas fases e como este estudo pode consubstanciar nosso posicionamento jurídico penal a respeito da ficção de Philip K. Dick diante do Direito Penal Brasileiro e os institutos da tentativa, desistência voluntária e crime consumado.

A metodologia empregada para a elaboração deste trabalho consistiu no uso do método hipotético-dedutivo, com pesquisa exploratória e bibliográfica, de abordagem predominantemente qualitativa.

\section{PACTO SOCIAL, CRIME E O DIREITO PENAL}

\footnotetext{
${ }^{4}$ Sistema ou doutrina que trata dos ilícitos penais e das penas, orientando-se por certezas prévias e criando dogmas (CUNHA, 2019).

${ }^{5}$ Parte da teoria do Direito Penal que estuda a etiologia do crime como fenômeno social, assim como trata do criminoso isoladamente, investiga as causas, os fatores individuais, as influências psicofísicas e biossociológicas determinantes da sua ação perniciosa, indicando as medidas aptas para reprimir as tendências delituosas, regenerá-lo e readaptá-lo ao convívio da comunidade (BITENCOURT, 2019).
} 
Atualmente um dos ramos mais apaixonantes das ciências jurídicas é sem dúvidas o direito penal muitas vezes também chamado de direito criminal, o primeiro nome foca na pena enquanto o segundo no crime. Este ramo do direito estuda o crime e aplicação de suas penas determinadas legalmente, apresentando regras para interpretação e aplicação do direito em casos reais (ANDRADE, 2017). Por isso, é fundamental que este estudo se inicie pela análise do surgimento e definição do crime, haja vista a diversidade de teorias que tentam explicá-lo, inclusive sobre os mais diversos prismas jusfilosóficos.

Assim, tomar-se-á por base a teoria contratualista de Thomas Hobbes ${ }^{6}$, que ao escrever o Livro Leviatã em 1651, propôs que no início da civilização os homens viviam em um estado de natureza que gerava conflitos e os colocavam uns contra os outros constantemente, por isso neste período prevalecia a força como meio de ordem e por via de consequência a manutenção do medo de lesões e mortes violentas a qualquer momento.

É neste contexto que surge o pacto social com a finalidade de estabelecer o Estado (Leviatã), onde os homens cedem parte de suas liberdades para um ser mais poderoso que o povo, mas ao mesmo tempo formado pelo povo e que passa a ter controle sobre o corpo social, efetivando-o com a criação de leis reguladoras de condutas e consequentemente sanções para os infratores, buscando assim a manutenção da ordem, harmonia e paz social (HOBBES, 2004).

A partir desse pacto social, que na teoria de Hobbes, não determina época e nem local de sua origem, entende-se que todo e qualquer grupo humano passou a possuir regras visando a punição daqueles que viessem a praticar atos contrários ao interesse da coletividade, como uma condição de sobrevivência do grupo. A obra de Philip P. Dick, tenta apresentar um contexto que represente o auge desse pacto social, ou seja, uma sociedade onde não há homicídios e para alcançar este objetivo passou a punir antes do delito acontecer. Antes de analisar como Philip P. Dick narrou esse método em sua literatura, é importante rememorar sucintamente como os sistemas e modalidades de punição penal se desenvolveram nas sociedades reais.

As modalidades de punição variaram ao longo dos séculos, tanto em relação ao tipo como na finalidade (GUIMARÃES, 2007). Em tempos mais remotos, a punição tinha como único fundamento a retribuição a alguém pelo mal causado com aspecto de vingança pessoal,

\footnotetext{
${ }^{6}$ Thomas Hobbes foi um matemático, teórico político e filósofo inglês, autor de Leviatã. Nasceu em 5 de abril de 1588 e morreu em 4 de dezembro de 1679 (HOBBES, 2004).
} 
mas sem se confundir com o uso da força arbitrária no estado de natureza representado por Hobbes, pois com o surgimento das sociedades esse tipo de punição, mesmo privada, passou a ser regulada formalmente como ocorreu por exemplo com a famigerada Lei de Talião ${ }^{7}$.

Com o mesmo objetivo punitivista também foram criadas normas para punir as pessoas em nome dos deuses, haja vista que o ilícito praticado nas sociedades teocráticas ofendiam a(s) divindade(s) daquele povo e portanto para manter ordem e paz, o culpado precisava ser sancionado em nome de um deus ou sistema religioso (GONÇALVES, 2019). Os estudiosos chamam essas duas modalidades de punição respectivamente de Vingança Privada e Vingança Divina.

Porém, essas fases mais antigas vão sendo superadas paulatinamente sem desaparecer totalmente e, em seu lugar surge um direito punitivo exercido pelo próprio Estado $^{8}$ soberano, chamada de Vingança Pública, cujo principal fundamento é o pacto social vislumbrado por Thomas Hobbes. Com esse sistema, retira-se das mãos da própria vítima ou familiares assim como dos sacerdotes, o poder de punir o culpado por um crime (pecado) que passa a ser exercido pelo Leviatã como o detentor de poder dado pelo próprio povo.

Diga-se ainda, que houve mudanças nos tipos de penas utilizados pelo Direito Penal a partir de sua evolução, variando de castigos físicos, banimento, morte, mutilações até chegar ao principal tipo de sanção atualmente conhecido: a prisão. A prisão como pena surge no século XVI, e a partir daí se transforma na principal forma de punir penalmente os infratores das normas estabelecidas, antes ela já existia, mas era usada como custódia para não deixar o culpado fugir até que chegasse o momento do julgamento (BITENCOURT, 2019).

No filme, percebe-se claramente que o modal punitivo ainda é a prisão, mas de uma forma diferenciada e a partir das tecnologias contextualizadas na ficção e imaginadas por Dick, sugerindo que no futuro haveria uma evolução dos sistemas carcerários precários que passaram a existir desde a segunda metade do século XVI, com péssimas condições de higiene, salubridade e portanto de sobrevivência digna para os condenados.

Assim, a pena é necessária para o sistema penal funcionar, sem a certeza da punição não há intimidação para cumprir a norma. É neste diapasão que o direito se apresenta como um instrumento para estabelecer a ordem pactuada através da criação de normas jurídicas e

\footnotetext{
${ }^{7}$ Consiste na rigorosa reciprocidade do crime e da pena. A perspectiva da lei de Talião é o de que uma pessoa que feriu outra pessoa deve ser penalizada em grau semelhante (GRECO, 2017).

${ }^{8}$ Estado deve ser entendido aqui como toda e qualquer forma de poder com controle político sobre um corpo social, e não necessariamente pela concepção atual de Estado moderno.
} 
consequentemente aplicação de sanções visando controlar os homens (BARATTA, 2002). Como a norma é legitimada pelo pacto social, quem descumpre pratica um ato ilícito e precisa ser punido, nisso consistindo o controle social do Estado.

É importante ressaltar que este controle social pode ser classificado como formal e informal, e a principal diferença consiste no uso de normas jurídicas e instituições do sistema de justiça do Estado para possibilitar esse controle. No controle informal não temos normas jurídicas positivadas com atuação punitiva do Estado, esse tipo de controle geralmente é feito através da educação familiar e escolar, nas igrejas, associações, dentre outros. Já o controle formal é realizado pelo Estado criando normas para proteger bens jurídicos e utilizando de seu aparato institucional para fazer cumprir a lei e/ou suas sanções (ANDRADE, 2017).

O crime, então, seria no aspecto do controle formal, a quebra destas normas jurídicas pelos cidadãos que fizeram o pacto social, ou seja, se configuraria como um ilícito penal. Por outra visão, de cunho sociológico, pode-se dizer que o crime seria um comportamento indesejável e intolerável socialmente que precisa ser sancionado para manter a paz social (SUMARIVA, 2017).

Nesses aspectos o surgimento e evolução do Direito Penal se confunde com a própria evolução da sociedade, pois ele surge inicialmente como norma para proteger a vida, a liberdade e a integridade física, bens tão caros para os homens que viviam no estado de natureza e precisavam de alguma forma de proteção, que doravante passou a ser uma proteção jurídica e por isso esses bens passam a ser qualificados de bens jurídicos (MOLINA; GOMES, 2010). Bens jurídicos, portanto, são bens existenciais (pessoais) valorados positivamente pelo Direito e protegidos, dentro e nos limites de uma determinada relação social conflitiva, por uma norma penal (BITENCOURT, 2019).

Para proteger os bens jurídicos de forma sistematizada, o direito penal se utiliza do princípio da intervenção mínima do Estado (ultima ratio) e seus desdobramentos de fragmentariedade e subsidiariedade. O princípio da ultima ratio reza que o estado deve intervir o mínimo possível nas condutas ilícitas dos cidadãos utilizando sanções de natureza penal, e aponta que para alcançar essa finalidade deve se importar em proteger apenas os bens jurídicos mais importantes e relevantes (como a vida, integridade física, patrimônio, dignidade sexual, etc) o que consiste no desdobramento da fragmentariedade, e também só atuará quando as demais formas de controle social ou outras normas jurídicas diversas das 
penais não puderem dar proteção efetiva a esses bens, o que é denominado de desdobramento da subsidiariedade (CUNHA, 2019).

Cediço então que o direito penal visa proteger bens jurídicos importantíssimos para o homem, e tendo em vista que uma das principais categorias da ficção de Dick é a política do "pré-crime", importa destacar a necessidade de analisar o tema da prevenção dos delitos como instrumento para evitar vilipêndio a esses bens. Segundo Bitencourt (2019), ao longo do tempo a pena evoluiu de uma concepção retributiva a uma concepção preventiva, onde a primeira tem o condão único e exclusivo de retribuir o mal causado pelo transgressor. $\mathrm{Na}$ concepção preventiva, entende-se que a norma existe para atuar na coletividade social por meio da intimidação, que tem a função de dissuadir os possíveis delinquentes da prática de delitos futuros, ameaçando-os com uma possível pena e, reforçando a lealdade de cada homem com pacto social para viver em paz e harmonia, quer antes de cometer o crime, quer evitando a reincidência para aqueles que já delinquiram e foram condenados (SHECAIRA, 2004).

Com base nesta sumária análise sobre a prevenção, é possível afirmar que a definição de prevenção utilizada pelo direito penal no mundo real e atual se difere da prevenção idealizada e apresentada na ficção desenvolvida por Philip Dick. Na ficção, a Divisão Policial do Pré-crime vai além da mera prevenção geral pela intimidação e reforço da norma jurídica estabelecida pelo pacto social, pois a divisão atua a partir de fatos ainda não ocorridos e dar seguimento ao processo e condenação de pessoas por atos não consumados, exercendo assim uma espécie de "hiperprevenção" que não se alinha com o direito penal moderno, já que o Estado não pode punir um cidadão por algo que inicialmente está apenas em pensamento ou ainda, com base em uma previsão de futuro sem qualquer rigor e provas de que irá de fato acontecer como previsto. Neste ponto a ficção realmente supera a realidade e não encontra acordo com ela, pelo menos dentro do ordenamento jurídico penal brasileiro garantista consubstanciado na Constituição Federal de 1988.

Urge ter em mente que o garantismo não se trata apenas de leis positivadas no ordenamento e sim na premissa de um Estado Democrático de Direito, desta forma o garantismo se apresenta como: um modelo normativo de Direito, que busca garantir os direitos dos cidadãos com a capacidade de punir do Estado; como uma teoria crítica do

\footnotetext{
${ }^{9}$ Refiro-me aqui a uma prevenção hiperbólica, exagerada, que ultrapassa os limites de atuação do direito penal, autorizando a prisão de indivíduos que não praticaram qualquer conduta típica.
} 
direito, que fundamenta-se na diferença entre a norma e a realidade, ocasionando uma separação entre o ser e o dever ser, contudo, o juiz não é obrigado a aplicar leis inválidas, mesmo as vigentes; e como uma filosofia política, impondo o dever de justificativa éticopolítica ao estado e ao direito, não aceitando somente a justificação jurídica (FERRAJOLI, 2006).

Portanto, não se pode aceitar uma norma jurídica, mesmo que legal e vigente, que venha violar direitos e garantias principiológicas e apenas porque foram desenhadas por meio de regras vigentes. A questão dos direitos, principalmente à liberdade, está muito além de mera conformação de regras jurídicas, elas perpassam pela necessidade de haver legitimidade do Estado para aplica-las de forma justa.

Até aqui já entendemos o que é o crime, a pena, e como o direito criminal evoluiu e deu fundamentos para Philip K. Dick apresentar sua versão/ficção sobre o sistema criminal responsável pelo atual controle social. Entretanto para analisar mais detidamente o cerne da obra de Dick é preciso mergulhar na dogmática desse sistema para comparar os casos apresentados no filme com o direito penal brasileiro, a fim de apontar semelhanças e diferenças entre a ficção e a realidade, e ao fim apresentar um posicionamento. Para facilitar o alcance este objetivo é elementar entender um outro aspecto do crime que está delineado entre os principais estudos dogmáticos do sistema penal brasileiro, ou seja, o seu conceito analítico $^{10}$.

\section{SUBSTRATOS DO CRIME, ITER CRIMINIS, TENTATIVA, DESISTÊNCIA VOLUNTÁRIA E CRIME CONSUMADO}

O estudo do crime sobre o prisma analítico, ou seja, de seus substratos e elementos precisa partir do entendimento da teoria tripartida que afirma ser o crime composto pelo fato típico, ilícito e culpável (GRECO, 2017).

O fato típico é formado pela conduta, resultado, nexo causal, e tipicidade. A conduta define-se como ação ou omissão humana direcionada a uma finalidade e pode ser dolosa ou

\footnotetext{
${ }^{10}$ Trata de um conceito onde se divide o crime em vários elementos (substratos) e subelementos, quebrando-o em pedaços a fim de analisar pormenorizadamente cada aspecto como um quebra-cabeças (GONÇALVES, 2019).
} 
culposa. Já o resultado trata das alterações que a conduta criminosa gera sobre o mundo exterior (resultado naturalístico) ou sobre o bem jurídico tutelado (resultado jurídico). O nexo causal é justamente o elo existente entre a conduta e o resultado, demonstrando assim, que tal resultado é consequência direta da conduta praticada. E por fim a tipicidade, que tem duas linhas de análise: a primeira como mera subsunção do caso concreto à norma jurídica penal incriminadora, conhecida como tipicidade formal; e a segunda como análise da relevância do bem jurídico para justificar a utilização do controle social penal, ou seja, o crivo do princípio da intervenção mínima (BITENCOURT, 2019).

O segundo substrato é a ilicitude ou antijuridicidade, na análise deste elemento é importante destacar o aspecto da indiciariedade na relação entre fato típico e ilícito, pois, dizse que se o fato é típico, então há indícios de que também seja ilícito. Entretanto, apesar de ter indícios nem sempre o fato típico será ilícito, havendo casos em que ele se justifica através do estado de necessidade, da legítima defesa, estrito cumprimento do dever legal e exercício regular de direito, tendo estas justificantes caráter legal porque estão previstas no nosso Código Penal. Mas, também é possível encontrar causas supralegais como o consentimento do ofendido, os ofendículos e outros. Tanto a causas legais como as supralegais excluem a ilicitude da conduta típica praticada pelo homem, levando a conclusão de que o crime não se conformou segundo a teoria tripartida (CUNHA, 2019).

O terceiro substrato é a culpabilidade, analisa-se aqui a imputabilidade nos aspectos da doença mental, da idade (menor de 18 anos) e da embriaguez; a potencial consciência da ilicitude que inclusive discute o erro de proibição, e por fim a inexigibilidade de conduta diversa, retratadas pela obediência hierárquica e a coação moral irresistível (GRECO, 2017).

Para ficar mais claro e inteligível essa divisão do conceito analítico de crime, veja a figura abaixo que demonstra essa estrutura em uma visão mais esquematizada.

Figura 1 - Estrutura Analítica do Crime 


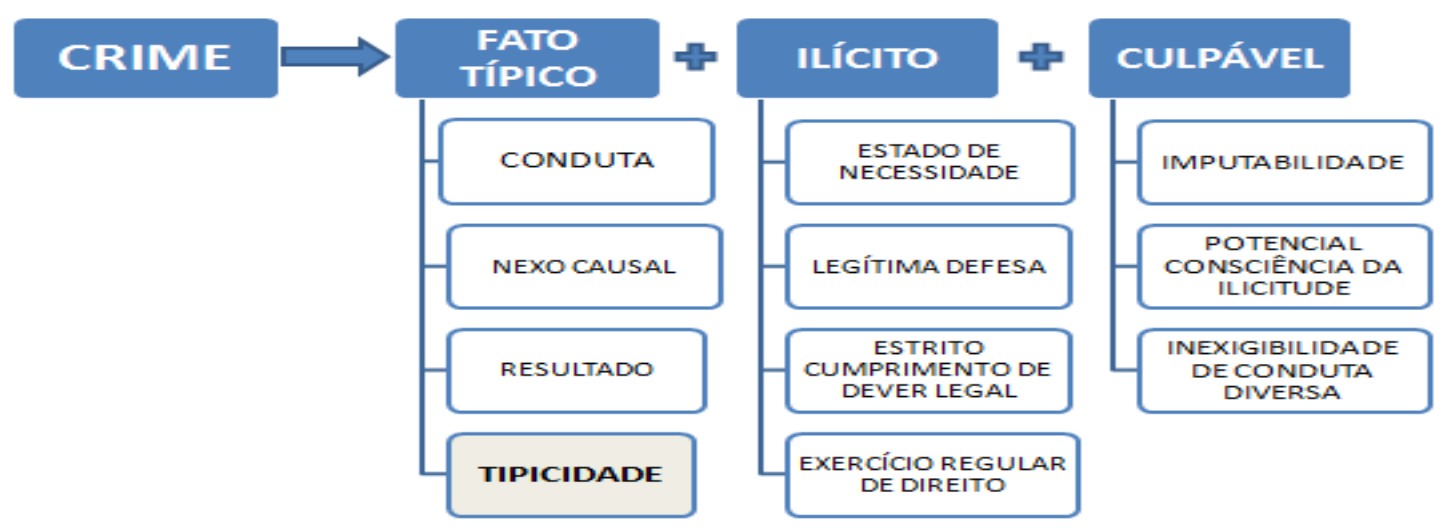

Fonte: criado pelo próprio autor

Visto a divisão de elementos desse conceito analítico, vamos nos deter com mais acuidade no estudo do fato típico, pois a conduta é conditio sine qua non para haver o crime, e se apresenta necessariamente como um ato exterior ao indivíduo, ou seja, para além de seus meros pensamentos. Assim, se o pensamento não se materializar em fatos, não podemos falar em cometimento de crime.

Seguindo esse raciocínio, quando analisamos o principal crime do filme, ou seja, o homicídio doloso, podemos verificar que para que houvesse a sua consumação, o autor do crime precisaria pensar o crime, se preparar para ele e executá-lo. Por isso é necessário que haja uma conduta humana para que ocorra um crime, o individuo precisa praticar uma ação, com vontade e consciência do que está fazendo (GONÇALVES, 2019), visando alcançar um resultado que neste caso é a morte de outro ser humano. Havendo relação de causa e efeito entre a conduta e a morte, e também previsão legal para punir essa conduta, teríamos então um fato típico de homicídio com previsão no art. 121 do nosso Código Penal.

Porém, a principal situação proposta por Philip K. Dick, é justamente evitar que o homicídio possa ser consumado, e punir o suposto autor antes mesmo dele praticar sua conduta delitiva. Poderia então haver crime sem ter conduta consumada? Para responder a essa indagação com base no direito penal brasileiro, vamos recorrer ao nosso Código Penal quando diz que:

Art. 14 - Diz-se o crime:

I - consumado, quando nele se reúnem todos os elementos de sua definição legal;

II - tentado, quando, iniciada a execução, não se consuma por circunstâncias alheias à vontade do agente.

Parágrafo único - Salvo disposição em contrário, pune-se a tentativa com a pena correspondente ao crime consumado, diminuída de um a dois terços.

Art. 15 - O agente que, voluntariamente, desiste de prosseguir na execução ou impede que o resultado se produza, só responde pelos atos já praticados. (grifo nosso) 
Veja-se que o Código Penal define o momento da consumação do crime pela reunião de todos os elementos de sua definição legal, estabelecendo também a possibilidade de punir uma conduta tipificada meramente como tentativa quando se iniciar a execução, mas não consumar o crime. Para esclarecer melhor esses dois institutos, a consumação e tentativa, é preciso recorrer ao estudo das fases do crime, ou seja, o seu caminho percorrido desde o momento em que ele é pensado até o momento da sua consumação.

Essas fases do crime são denominadas de iter criminis ou caminho do crime e consistem em analisar que:

Desde que o desígnio criminoso aparece no foro íntimo da pessoa, como um produto da imaginação, até que se opere a consumação do delito, existe um processo, parte do qual não se exterioriza, necessariamente, de maneira a ser observado por algum espectador, excluído o próprio autor. A este processo dá-se o nome de iter criminis ou caminho do crime, que significa o conjunto de etapas que se sucedem, cronologicamente, no desenvolvimento do delito (ZAFFARONI; PIERANGELI, 1995, p. 13)

O iter criminis começa com a cogitação, em seguida se tem os atos preparatórios, depois a execução e finalmente a consumação (GRECO, 2017).

A cogitação se caracteriza como uma fase intrapsíquica, haja vista que se passa na mente do criminoso, nos seus pensamentos, mas sem exteriorização ou materialização de qualquer ação. Uma vez pensado o crime, o sujeito passa a praticar atos preparatórios que visam alcançar o resultado pretendido como adquirir instrumentos do crime, fazer reuniões, preparar o local do crime, analisar a rotina da vítima, etc. É importante frisar que a lei penal brasileira não pune a cogitação em hipótese alguma e, somente em casos excepcionais sanciona os atos preparatórios, como nos crimes de associação criminosa, previsto no artigo 288 do Código Penal (CUNHA, 2019).

Quando iniciada a execução do crime, é possível que os atos executórios sejam praticados até alcançar seu objetivo almejado, isto é, a consumação do delito como determina o art. 14, I, CP. Por outro lado, se não houver a consumação, duas possibilidades existem: a primeira ocorre quando o agente é interrompido por circunstâncias alheias a sua vontade o que caracteriza a conduta apenas como crime na forma tentada conforme o art. 14, II, CP, respondendo assim com pena reduzida de um a dois terços; a segunda se refere a desistência de alcançar o objetivo visado pelo agente, isso ocorre de forma voluntária mesmo que já tenha iniciado os atos executórios, mas sem ter consumado o delito, respondendo portanto apenas 
pelos atos já praticados se forem condutas típicas, conforme o art. 15 do Código Penal (BITENCOURT, 2019).

Veja abaixo um quadro demonstrativo das principais semelhanças e diferenças entre esses dois institutos.

QUADRO 01: Principais diferenças entre a tentativa e desistência voluntária

\begin{tabular}{|c|c|}
\hline TENTATIVA SIMPLES & DESISTÊNCIA VOLUNTÁRIA \\
\hline Início da execução; & Início da execução; \\
\hline $\begin{array}{c}\text { Não consumação por circunstâncias } \\
\text { alheias à vontade do agente; }\end{array}$ & $\begin{array}{c}\text { Não consumação por circunstâncias } \\
\text { inerentes à vontade do agente; }\end{array}$ \\
\hline $\begin{array}{c}\text { Pena do crime consumado, diminuída de um } \\
\text { a dois terços. }\end{array}$ & $\begin{array}{c}\text { Só responde pelos atos já praticados até a } \\
\text { desistência. }\end{array}$ \\
\hline
\end{tabular}

Fonte: criado pelo próprio autor

Para haver tentativa ou desistência voluntária é fundamental que a execução tenha se iniciado (GONÇALVES, 2019), por isso, conhecer o momento que acabam os atos preparatórios e se iniciam os atos da execução é fundamental para o nosso estudo. Pois, se considerarmos apenas a prática dos atos preparatórios sem iniciar a execução, regra geral não haverá punição, mas se o indivíduo tiver iniciado os atos de execução, no mínimo responderá por tentativa ou pelos atos praticados anteriormente, conforme vimos no caso de desistência voluntária. Todavia, distinguir onde termina a preparação e começa a execução não é uma tarefa fácil e até os dias atuais os estudiosos do Direito Penal ainda sentem dificuldades para estabelecer este limite.

Para resolver essa celeuma, as teorias mais aceitas e utilizadas visando determinar o momento que se encerra os atos preparatórios e se iniciam os atos executórios ainda são a teoria objetiva formal e material. A primeira trata da necessidade do agente iniciar a prática de uma conduta descrita no verbo do tipo penal incriminador, ou seja, enquanto não praticar o verbo não se iniciam os atos de execução; a segunda indica que mesmo que não se tenha iniciado atos de execução do verbo, mas se há prática de ações que tenham vinculação com a conduta típica sendo necessariamente uma parte integrante dela e que coloquem em perigo de forma imediata os bens jurídicos tutelados pela norma penal, também devem ser considerados início dos atos executórios (GRECO, 2017).

Voltando à análise da ficção e realidade jurídica, veja-se, que no filme existem duas cenas que segundo o enredo parecem se tratar de situações semelhantes mas juridicamente são 
diferentes, pois apesar de toda a trama versar sobre punir alguém por um crime que não aconteceu no mundo real e concreto, quando analisamos os aspectos jurídico-penal à luz do direito concluímos que as consequências são diferentes e por isso afirmamos que são cenas e situações distintas.

O primeiro destes cenários aparece logo no início do filme quando a divisão précrime toma conhecimento de que um marido traído irá assassinar sua esposa por conta da infidelidade. No dia do possível crime, a equipe busca insistentemente encontrar o local para impedir que ocorra a execução e consumação do assassinato. Quando a equipe encontra o local, Anderton (líder da equipe de captura) consegue entrar na casa e chega até o quarto onde se passa a cena do possível crime, neste momento o marido traído está com uma tesoura na mão ao lado de sua esposa que se encontra deitada e indefesa, e neste instante ele inicia um movimento com o braço para apunhalá-la, é quando Anderson adentra o quarto e segura o braço do marido que já estava a poucos centímetros de atingir o corpo da esposa com a tesoura, impedindo assim que o homicídio ou lesão acontecesse. Em seguida é dado voz de prisão ao suspeito sobre a alegação de que a sua prisão se refere ao 'assassinato futuro' da sua esposa, que na realidade não aconteceu.

A análise jurídica neste caso encontra perfeita correspondência com nosso ordenamento jurídico penal brasileiro para fins de adequação típica, pois segundo a teoria objetiva formal e material, o marido iniciou os atos de execução mas não se consumou por circunstâncias alheias à sua vontade, pois foi impedido pelos policiais, o que caracteriza o crime de homicídio tentado.

Neste caso, destaca-se inadequado apenas o enquadramento formal na fala do policial no ato da prisão, pois o acusado deveria ser preso em flagrante por tentativa de homicídio e não pelo homicídio consumado futuro e virtual de sua esposa, que continuou viva e com sua integridade física intacta. Nesta cena portanto, a prisão é devida, legal e o crime encontra adequação típica no Código Penal Brasileiro, mas não por homicídio consumado. É portanto, inconcebível punir alguém pela morte de outra pessoa que continua viva no contexto apresentado.

O segundo cenário é mais intrigante, pois Anderton enquanto trabalha normalmente na divisão policial descobre que acontecerá outro possível assassinato, e para sua surpresa, desta vez ele é o próprio acusado. Ironicamente Anderton não se entrega para ser preso e nem revela para seus pares e superiores o que descobriu, mas pela primeira vez coloca em xeque a 
legitimidade e segurança do sistema e previsão dos precogs que ele tanto defendia e confiava como expressão de justiça, não aceitando que ele poderia cometer tal crime no futuro. Anderton então foge para não ser preso, e vai em busca de respostas ou solução para demonstrar que ele não cometerá tal assassinato, neste interim a divisão toma conhecimento do crime que iria acontecer e de forma imediata a polícia pré-crime começa uma perseguição para o prender.

Veja que neste momento do filme, se a prisão de Anderton acontecesse seria ilegal do ponto de vista do nosso ordenamento brasileiro, posto que ele sequer praticou atos preparatórios e não iniciou qualquer ato executório de um homicídio, o que impede que exista conduta típica se fosse um caso real. Portanto, sua prisão seria baseada apenas em um crime virtual a partir de uma previsão futura, mas não real. Nem mesmo a tentativa seria possível neste momento, como ocorreu com a primeira cena de prisão do filme, onde o marido está no local do crime e deu início os atos de execução. No caso de Anderton, ele nem sabia ainda a localização da cena do crime, nem tampouco quem seria a sua possível vítima, estava justamente fugindo para encontrar essas respostas.

No desenrolar da trama finalmente John Anderton se encontra com a suposta vítima do homicídio que seria executado por ele previsto pelos precogs. Na cena ele trava uma luta corporal onde agride e é agredido, e em seguida saca de uma arma, aponta para a vítima, mas quando o relógio marca a hora exata de consumar o assassinato segundo a previsão, ele desiste de puxar o gatilho e não atira, demonstrando que não há um determinismo criminal e a decisão final de cometer ou não o crime é dele.

Nota-se que apesar de ter iniciado os atos executórios quando apontou a arma para vítima (teoria objetiva-material), Anderton desiste voluntariamente de continuar a conduta, o que não pode caracterizar a tentativa de homicídio, já que na tentativa a não consumação ocorre por circunstâncias alheias à sua vontade e neste caso foi ele mesmo que decidiu não consumar. Entende-se que nesta cena ocorreu o instituto da desistência voluntária prevista no art. 15 do nosso Código Penal, onde o acusado não responde nem pela tentativa e nem pelo crime consumado, mas somente pelos atos já praticados, o que nesse caso se trata apenas de lesões corporais (art. 129 do Código Penal Brasileiro) por conta da luta travada anteriormente entre eles.

\section{CONSIDERAÇÕES FINAIS}

Revista de Direito, Arte e Literatura | e-ISSN: 2525-9911 | Belém | v. 5 | n. 2 | p. 99 - 115 | Jul/Dez. 2019. 
Neste rápido estudo fizemos uma análise entre algumas cenas do filme Minority Report e a dogmática penal brasileira. Temos ciência que muitos temas do direito penal, processo penal, criminologia, vitimologia, penalogia, política criminal, dentre outras áreas podem ser exaustivamente explorados com foco nesta ficção.

Porém, delimitamos apresentar apenas apanágios dos sistemas penais, rememorando o que é o pacto social, como o direito penal e a ideia de crime surgem a partir deste pacto, sobre o controle social formal penal estabelecido e legitimado pelo estado, os bens jurídicos protegidos e princípios envolvidos neste sistema. Também tratamos da punição como condição de cumprimento da lei, suas modalidades e evolução, tipos e como ela cumpre um papel preventivo de intimidação e reforço do pacto social.

No primeiro momento o foco era apresentar o sistema punitivo penal existente no mundo real que deu base para Philip Dick construir sua ficção paralela e com algumas distinções da realidade. Isso é importante no estudo do direito e da arte na exata medida em que gera poder de reflexão sobre o que era, como é, e como poderia ou poderá vir a ser.

$\mathrm{Na}$ segunda parte, passamos a explorar a dogmática penal brasileira, principalmente no que tange ao conceito analítico de crime e seus substratos. Pois, para ter crime precisa haver uma conduta típica que passa por fases: a cogitação, preparação, execução e consumação. Sem o início da execução, como regra geral, não pode haver crime. A partir do iter criminis podemos estudar ainda os institutos do crime consumado, crime tentado e desistência voluntária previstas no nosso Código Penal e que foram essenciais para a análise e comparação proposta inicialmente.

No fim da análise, separamos as duas principais cenas que apresentam prisões por crimes que ainda iriam acontecer, e utilizando de uma exegese baseada nos institutos estudados, concluímos que na primeira cena deveria ser aplicado a tentativa de homicídio e na segunda apenas a desistência voluntária.

A obra literária e o filme analisados apresentam para quem lê ou assiste uma espécie de medida alternativa evoluída para reduzir ou até mesmo acabar com os assassinatos no seio social, que segundo Hobbes, eram latentes desde o estado de natureza dos homens. Entretanto, não se pode olvidar que o direito não pode se basear em meras previsões do futuro, e prender e condenar alguém por conta de tal previsão, tendo que respeitar as regras do pacto social efetivado entre os homens. 
É notável ainda, como cada vez mais há filmes, séries, novelas, romances e outras forma de expressão artística que envolvem questões de direito e justiça, aumentando o interesse de qualquer pessoa sobre estes temas, independentemente de ser estudante de direito, professor, jurista ou qualquer outro profissional de área congênere. Por isso, as análises e debates envolvendo direito e arte com resultados apresentados em forma de produção científica são extremamente relevantes para enriquecer o conhecimento de quem atua na área e ajudar a sociedade em geral a entender mais sobre as ciências jurídicas, mesmo que por um viés e interesse mais lúdico como o cinema.

Apesar de termos poucas páginas para tratar da temática direito e arte em relação ao filme "O relatório minoritário", este estudo se apresentou de grande valia para exercitar, demonstrar e motivar o debate jurídico a partir da interdisciplinaridade com a arte, tratando-se de uma prática diferente e simples, entretanto deveras rica na propulsão do processo de ensino -aprendizagem do direito e sua reflexão por meio de outra forma de pensar o mundo. Diversas outras análises poderiam ser feitas neste estudo, mas limitamos a discussão apenas à dogmática penal nas abordagens que nos propomos, e assim outras preocupações serão frutos de novos trabalhos oportunos.

\section{REFERÊNCIAS}

ANDRADE, Vera Regina Pereira de. Pelas mãos da criminologia: O controle penal para além da (des) ilusão. Rio de Janeiro: Revan, 2017 (Coleção Pensamento Criminológico).

ANGHER, Anne Joyce (org). Vademecum Acadêmico de Direito. 25. ed. São Paulo: Rideel, 2019.

BARATTA, Alessandro. Criminologia Crítica e Crítica do Direito Penal: introdução à sociologia do direito penal. 3.ed. Rio de Janeiro: Editora Revan, 2002.

BITENCOURT, Cezar Roberto. Tratado de Direito Penal, Parte Geral, volume 1. São Paulo: Saraiva, 2019.

CARRÉRE, Emmanuel. Eu estou vivo e vocês estão mortos: A vida de Philip K. Dick. 1. ed. São Paulo: Editora Aleph, 2016.

CUNHA, Rogério Sanches. Manual de Direito Penal: Parte Geral. Salvador: JusPodivm, 2019. 
FERRAJOLI, Luigi. Direito e razão: teoria do garantismo penal. Tradução Ana Paula Zomer Sica e outros. São Paulo: Revista dos Tribunais, 2006.

GONÇALVES, Victor Eduardo Rios. Direito penal esquematizado: parte geral. São Paulo: Saraiva, 2019.

GRECO, Rogério. Curso de Direito Penal, Parte Geral, volume I. 19. ed. Niterói: Impetus, 2017.

GUIMARÃES, Claudio Alberto Gabriel. Funções da pena privativa de liberdade no sistema penal capitalista. Rio de Janeiro: Renovar, 2007.

HOBBES, Thomas de Malmesbury. Leviatã ou Matéria, forma e poder de um Estado eclesiástico e civil. Tradução de João Paulo Monteiro e Maria Beatriz Nizza da Silva. São Paulo: Editora Nova Cultural, 2004 (Coleção Os Pensadores).

MOLINA, Antonio García-Pablos de; GOMES, Luiz Flávio. Criminologia. 7. ed. São Paulo: Editora Revista dos Tribunais, 2010.

SHECAIRA, Sergio Salomão. Criminologia. São Paulo: Editora Revista dos Tribunais, 2004.

SUMARIVA, Paulo. Criminologia: Teoria e Prática. 4. ed. Niterói: Impetus, 2017. 